\title{
HUBUNGAN POLA MINUM DAN JUMLAH KONSUMSI CAIRAN DARI MINUMAN TERHADAP STATUS DEHIDRASI SANTRIWATI USIA 16-18 TAHUN DI PONDOK PESANTREN DARUNNAJAH JAKARTA SELATAN TAHUN 2012
}

\author{
Ratnasari, Moesijanti Soekatri \\ Jurusan Gizi, Politeknik Kesehatan Kemenkes Jakarta II \\ ratna_gizi.depkes@yahoo.com
}

\begin{abstract}
ABSTRAK
Cairan adalah apa saja yang mengandung air. Cairan bisa didapat dari makanan dan minuman. Kehilangan air tubuh manusia apabila tidak diimbangi dengan pemasukan cairan yang cukup akan mengalami dehidrasi. Dalam penelitian ini, cairan yang diteliti hanya yang berasal dari minuman. Tujuan dari penelitian ini adalah untuk mengetahui hubungan pola minum (jenis, frekwensi dan merek), serta jumlah yang dikonsumsi dari minuman saja, terhadap status dehidrasi santriwati di Pondok Pesantren Darunnajah Jakarta Selatan. Penelitian ini adalah cross-sectional. Populasinya adalah santriwati berusia 16-18 tahun yang tinggal di asrama Pondok Pesantren Darunnajah. Sampel adalah seluruh santriwati yang memenuhi kriteria, jumlahnya 35 santriwati. Data yang dikumpulkan meliputi nama dan usia, pola konsumsi minuman, serta jumlah cairan yang diminum melalui wawancara menggunakan kuesioner. Untuk data status dehidrasi diperoleh melalui pengujian urin menggunakan indikator Urinalysis Reagen Strips. Hasil penelitian menunjukkan bahwa sebagian kecil sampel mengalami dehidrasi $(17,1 \%)$ walaupun mereka telah mengonsumsi sampai 7 jenis minuman $(31,6 \%)$. Hasil analisis cenderung menunjukkan adanya hubungan pola dan jumlah konsumsi cairan dari minuman masing masing terhadap status dehidrasi.
\end{abstract}

Kata kunci: pola konsumsi cairan, jumlah konsumsi cairan, status dehidrasi

\section{ABSTRACT}

\section{THE RELATIONSHIP BETWEEN DRINKING PATTERN AND THE AMOUNT OF WATER FROM DRINK TO DEHIDRATION STATUS OF FEMALE STUDENT IN “DARUNNAJAH” ISLAMIC BOARDING SCHOOL, SOUTH JAKARTA IN 2012}

Water is essensial nutrient for life which comes from food and drink. Water describes everything categorized as drink in liquids form. Lack of water may lead to dehydration. The study aimed to assess the comsumption of water from drinking in relation to drinking pattern (type, frequency, and brand), and the amount of water consumed to dehydration status infemale stundent in 'Darunnajah' Islamic Boarding School, South Jakarta. The study was cross sectional involved 16-18 years old who lived in dormitory. The criterias of subject are healthy, not in menstrual period and not cuurently taking medication. From 35 students, urines were collected and dehydration status was determined using Urinalysis Reagen Strips indicator. Information on drinking water pattern and amount of water were taken using questionnaire through interview. The water consumption was called as less if below $1200 \mathrm{ml}$. The results show that student with dehydration status was $17,1 \%$ even they already consumed 7 type of drinks (31.6\%). Based on table analysis indicated that there were a tendency of relationship between drinking source pattern and amount of water to dehydration status.

Keywords: drinking pattern, amount of drinking pattern,dehydration status

\section{PENDAHULUAN}

$S$ ekitar 71 persen dari permukaan bumi kita adalah air, dimana air merupakan kebutuhan pokok yang sangat penting bagi kelangsungan makhluk hidup. Selain merupakan bagian terbesar dari bumi ini, air juga menjadi komponen utama dalam tubuh manusia. Pada pria dewasa, 55 persen sampai 60 persen berat tubuhnya adalah air dan pada perempuan dewasa, 50 persen sampai 60 persen berat tubuhnya adalah air. ${ }^{1}$

Air mempunyai fungsi dalam berbagai proses penting pada tubuh manusia, seperti pengatur suhu tubuh, zat pelarut, pembentuk 
sel dan cairan tubuh, pelumas dan bantalan, media transportasi, dan media eliminasi sisa metabolisme. Sayangnya, air seringkali terlupakan sebagai zat gizi yang penting bagi tubuh. Tubuh tidak dapat memenuhi seluruh kebutuhan akan air. Oleh karena itu, air perlu dipenuhi manusia melalui asupan air yang cukup. ${ }^{1}$

Menurut Sandjaja, dkk., kekurangan makan dapat bertahan dalam waktu yang lebih lama dibandingkan tanpa air yang hanya bisa bertahan selama beberapa hari. ${ }^{2}$ Pemenuhan kebutuhan manusia akan cairan diperoleh dari konsumsi air minum, air yang terkandung dalam makanan, dan air hasil metabolisme tubuh. Persentase terbesar air dalam tubuh manusia didapat dari makanan dan minuman yang dikonsumsi sehari-hari. Sedangkan secara normal, dalam satu hari tubuh akan kehilangan cairan melalui ginjal, kulit, paru-paru maupun feses. Untuk menjaga agar kondisi dan fungsi cairan tubuh tidak terganggu, maka kehilangan cairan tersebut harus diganti. ${ }^{1}$

Salah satu kebiasaan yang salah adalah mengonsumsi air hanya ketika haus. Hal ini bisa menyebabkan dehidrasi. Dehidrasi merupakan kondisi kekurangan cairan tubuh karena jumlah cairan yang keluar lebih banyak daripada jumlah cairan yang masuk. ${ }^{3}$ Faktor-faktor yang menyebabkan kebutuhan tubuh akan cairan meningkat yaitu usia, jenis kelamin, aktivitas, suhu, stres, sakit, dan diet. ${ }^{4}$ Dehidrasi terbagi menjadi tiga tingkat, yaitu dehidrasi ringan, dehidrasi sedang, dan dehidrasi berat. ${ }^{5}$

The Indonesian Hydration Regional Study mengungkapkan bahwa 46,1 persen dari 1200 sampel yang diteliti mengalami dehidrasi ringan. Kejadian ini banyak terjadi pada remaja $(49,5 \%)$ dibandingkan orang dewasa (42,5\%). Berbagai penelitian menunjukkan bahwa kurang air berdampak buruk bagi kesehatan atau meningkatkan resiko kejadian berbagai penyakit, seperti sembelit, kram, batu ginjal, infeksi saluran kemih, dan lain-lain. Selain itu juga berdampak buruk pada stamina, daya ingat dan kecerdasan. Kurang air satu persen berat badan akan mulai mengganggu kerja otak dan kemampuan berpikir, dan kurang air dua persen berat badan menyebabkan penurunan konsentrasi dan daya ingat sesaat. Hal ini akan berdampak buruk pada kecerdasan dan pendidikannya. ${ }^{1}$
Sampai saat ini belum banyak studi di Indonesia tentang pola dan jumlah konsumsi cairan yang berasal dari minuman pada kelompok remaja. Penelitian ini secara umum mengkaji pola konsumsi cairan dari minuman dan jumlah konsumsi cairan dari minuman terhadap status dehidrasinya. Tujuan khusus penelitian adalah: 1) mengidentifikasi pola konsumsi minuman santriwati meliputi jenis dan frekuensi minuman, 2) menghitung jumlah konsumsi cairan dari minuman yang dikonsumsi santriwati selama satu hari, dan 3) melakukan tes berat jenis urin untuk menentukan status dehidrasi santriwati.

\section{METODE PENELITIAN}

Penelitian ini dilakukan di Pondok Pesantren Darunnajah daerah Pesanggrahan Jakarta Selatan pada tanggal 27-29 Juni 2012. Rancangan penelitian yang digunakan berupa rancangan cross sectional dimana variabel bebas dan terikat diteliti pada waktu yang bersamaan.

Populasi yang dimaksud pada penelitian ini adalah semua santriwati kelas 1 dan kelas 2 Aliyah yang tinggal di asrama Pondok Pesantren Darunnajah dengan jumlah 300 orang santriwati usia 16-18 tahun. Pengambilan sampel penelitian dilakukan dengan cara purposive yaitu mengambil semua santriwati yang memenuhi kriteria sebagai berikut:

a. Santriwati yang tinggal di Pondok Pesantren Darunnajah

b. Berusia antara 16-18 tahun

c. Kelas 1 atau 2 Aliyah

d. Bersedia menjadi responden

e. Dalam keadaan sehat (tidak sakit)

f. Dalam keadaan tidak menstruasi

g. Tidak mengonsumsi obat-obatan diuretic

Jumlah santriwati usia 16-18 tahun adalah 300 orang, namun yang memenuhi kriteria untuk menjadi sampel hanya sebanyak 35 orang.

Data yang dikumpulkan meliputi data karakteristik sampel, pola konsumsi cairan dari minuman, jumlah konsumsi cairan dari minuman serta data status dehidrasi. Data karakteristik sampel berupa nama dan usia didapatkan melalui wawancara langsung dengan sampel yang kemudian hasilnya dicatat dalam lembar kuesioner. 
Data pola konsumsi minuman didapat melalui wawancara dengan menggunakan bantuan kuesioner, dimana peneliti menanyakan jenis dan frekuensi minuman yang diminum oleh sampel selama satu bulan terakhir. Data yang didapat kemudian dikatagorikan sering (jika dikonsumsi $\geq 3 x$ sehari), jarang (jika dikonsumsi $<3 x$ sehari, dan tidak pernah (jika dikonsumsi 0 kali sehari).

Data jumlah konsumsi cairan dari minuman didapat melalui pengisian kuesioner "record minuman" yang dilakukan sendiri oleh sampel selama satu hari dengan bantuan alat ukur berupa "gelas contoh" untuk memudahkan penghitungan jumlah cairan yang diminum. Data yang didapat kemudian dikatagorikan oleh peneliti kedalam dua katagori sesuai dengan acuan yang dikemukakan Hardinsyah (2011), yaitu cukup (bila jumlah cairan yang diminum selama 1 hari $\geq 1200 \mathrm{ml}$ ) dan kurang (bila jumlah cairan yang diminum selama 1 hari $<1200 \mathrm{ml}$ ).

Data status dehidrasi didapatkan dengan cara mengetes urin pagi sampel yang sehari sebelumnya telah dicatat jumlah konsumsi cairannya, dengan menggunakan alat "Urinalysis Reagens Strips" didapatkan nilai berat jenis urin dari masing-masing sampel. Nilai berat jenis urin ini kemudian dikatagorikan kedalam 2 katagori, yaitu tidak dehidrasi (jika nilai berat jenis urin antara $1,005-1,020$ ) dan dehidrasi (jika nilai berat jenis urin $>1,020$ ).

Pengumpulan data dilakukan oleh tiga orang yang terdiri dari satu orang peneliti utama, satu orang peneliti pembantu yang sebelumnya telah dijelaskan tata cara penelitiannya, dan satu orang lagi yaitu petugas kesehatan klinik untuk membantu dalam mengecek berat jenis urin santriwati.

Analisis dilakukan secara deskriptif untuk menggambarkan jumlah konsumsi cairan dari minuman dan status dehidrasi santriwati. Analisis tabel silang digunakan untuk menganalisis hubungan pola konsumsi cairan dari minuman terhadap status dehidrasi dan hubungan jumlah konsumsi cairan dari minuman terhadap status dehidrasi.

\section{HASIL}

\section{Usia sampel penelitian}

Dari 35 sampel yang diteliti dengan rentang usia antara 16-18 tahun, rata-rata usia remaja yang menjadi sampel penelitian yaitu paling banyak yang berusia 17 tahun (45,7\%) dan yang paling sedikit yaitu sampel berusia 18 tahun $(11,4 \%)$.

Usia sampel berkisar antara 16 sampai 18 tahun dengan jumlah yang terkecil pada usia 11,4 persen, sementara persentase sampel usia 16 dan 17 tahun kurang lebih sama besar (masing masing, 42,9 dan 45,7 persen)

\section{Pola Konsumsi Cairan dari Minuman}

Data yang diambil pada pola konsumsi ini berupa jenis dan frekuensi minuman yang diminum oleh santriwati selama satu bulan terakhir. Data yang terkumpul meliputi jenis minuman yang diminum dan frekuensi pengonsumsiannya, jawaban dicatat dalam kuesioner.

Tabel 1

Distribusi Pola Konsumsi Cairan Dari Minuman Sampel

\begin{tabular}{lcccccc}
\hline \multirow{2}{*}{ Jenis minuman } & \multicolumn{9}{c}{ Frekuensi } \\
\cline { 2 - 7 } & \multicolumn{2}{c}{ Sering $(\geq 3 \mathrm{x} / \mathrm{hari})$} & \multicolumn{2}{c}{ Jarang $(<3 \mathrm{x} / \mathrm{hari})$} & \multicolumn{2}{c}{ Tidak Pernah } \\
\cline { 2 - 7 } Air minum tawar & $\mathrm{n}$ & $\%$ & $\mathrm{n}$ & $\%$ & $\mathrm{n}$ & $\%$ \\
Teh & 35 & 100,0 & 0 & 0 & 0 & 0 \\
Kopi & 0 & 0 & 33 & 94,3 & 2 & 5,7 \\
Susu & 0 & 0 & 24 & 68,6 & 11 & 31,4 \\
Jus & 4 & 11,4 & 31 & 88,6 & 0 & 0 \\
Sari buah & 0 & 0 & 31 & 88,6 & 4 & 11,4 \\
Sirup & 0 & 0 & 26 & 74,3 & 9 & 25,7 \\
softdrink & 0 & 0 & 23 & 65,7 & 12 & 34,3 \\
Minuman elektrolit & 0 & 0 & 25 & 71,4 & 10 & 28,6 \\
& 0 & 0 & 24 & 68,6 & 11 & 31,4 \\
\hline
\end{tabular}


Jenis minuman diambil berdasarkan penelitian mengenai jenis minuman yang paling sering dikonsumsi oleh masyarakat Indonesia, sedangkan frekuensi minuman diambil berdasarkan rata-rata konsumsi minuman tersebut.

Berdasarkan hasil yang didapat, air minum tawar adalah jenis minuman yang paling banyak dikonsumsi oleh santriwati dengan frekuensi sering $(100 \%)$. Sedangkan jenis minuman lainnya seperti teh, susu, jus, dan sari buah dikonsumsi oleh sebagian besar santriwati dengan frekuensi jarang. Jenis minuman yang tidak pernah dikonsumsi oleh santriwati paling banyak yaitu pada pilihan jenis minuman sirup $(34,3 \%)$, kopi $(31,4 \%)$, minuman elektrolit $(31,4 \%)$, dan softdrink $(28,6 \%)$.

\section{Jumlah Konsumsi Cairan dari Minuman}

Data jumlah konsumsi cairan dari minuman didapat melalui penghitungan jumlah cairan yang diminum oleh santriwati selama satu hari, mulai dari bangun tidur, hingga saat santriwati akan tidur kembali. Jumlah cairan tersebut diisi oleh santriwati dalam kuesioner dengan menggunakan URT (ukuran rumah tangga) yang kemudian selanjutnya akan dikonversikan oleh peneliti kedalam milliliter.

Untuk membantu peneliti dalam mempermudah penghitungan cairan, peneliti memberikan "gelas contoh" sebagai gelas bantu santriwati. Gelas contoh tersebut telah dimodifikasi oleh peneliti sehingga terdapat garis-garis mililiternya. Peneliti membuat kesepakatan dengan santriwati untuk menggunakan gelas tersebut sebagai alat minumnya selama penelitian berlangsung. Santriwati diminta untuk melihat air yang akan diminumnya berada pada garis mililiter mana, kemudian dicatat dalam kuesioner sehingga kevalidan jumlah cairan tersebut bisa dipertanggungjawabkan.

Setelah santriwati mencatat jumlah cairan dalam bentuk URT, kemudian peneliti mengonversikannya ke dalam bentuk mililiter. Jumlah cairan yang dikonsumsi oleh masingmasing santriwati kemudian dikatagorikan sesuai katagori yang telah ditentukan oleh peneliti berdasarkan rujukan. Terdapat 2 katagori, yaitu cukup dan kurang. Dikatakan cukup bila jumlah cairan yang dikonsumsi santriwati $\geq 1200 \mathrm{ml} / \mathrm{hari}$, dikatakan kurang bila jumlah cairan yang dikonsumsi santriwati kurang dari $1200 \mathrm{ml} / \mathrm{hari}$. Katagori ini didapatkan berdasarkan teori yang dikemukakan oleh Hardinsyah, dimana wanita dengan usia 16-18 tahun memiliki kebutuhan cairan $2100 \mathrm{ml}$ yang dipenuhi oleh manusia melalui tiga sumber, yaitu melalui asupan minuman sebesar 55 persen, makanan 35 persen, serta hasil metabolisme sebesar 10 persen. ${ }^{1}$ Peneliti hanya meneliti jumlah asupan cairan yang berasal dari minuman saja, cut off point yang didapat adalah sebesar 55 persen dari $2100 \mathrm{ml}$ yaitu $\pm 1200 \mathrm{ml}$.

Berdasarkan hasil penelitian yang didapat, santriwati yang mengonsumsi jumlah cairan dalam katagori cukup sebesar 54,3 persen, dan santriwati yang mengonsumsi cairan dalam katagori kurang sebanyak 45,7 persen.

\section{Status Dehidrasi}

Dehidrasi merupakan suatu kondisi dimana jumlah cairan yang keluar lebih banyak dibandingkan jumlah air yang masuk tubuh. ${ }^{4}$ Data status dehidrasi yang dimaksud dalam penelitian ini adalah data nilai berat jenis urin dari masing-masing santriwati yang ditest dengan menggunakan alat "Urinalysisi Reagens Strips", kemudian setelah mendapatkan nilai berat jenisnya lalu dikelompokkan kedalam dua katagori, yaitu katagori tidak dehidrasi dan katagori dehidrasi. Dikatakan tidak dehidrasi apabila nilai berat jenis urin yang ditest berada pada rentang antara 1,005-1,020. Sedangkan dikatakan dehidrasi apabila nilai berat jenis urin yang diuji berada pada angka $>1,020$.

Urin yang diuji oleh petugas laboratorium ini merupakan urin pagi (urin bangun tidur) yang sehari sebelumnya telah dilakukan pencatatan jumlah konsumsi cairan yang diminum oleh santriwati selama satu hari.

Hal ini dilakukan supaya peneliti dapat mengetahui efek dari jumlah cairan yang dikonsumsi terhadap status dehidrasinya. Berdasarkan hasil penelitian yang didapat menunjukkan bahwa sebagian besar santriwati tidak mengalami dehidrasi (82,9\%). Meskipun demikian, masih juga terdapat santriwati yang mengalami dehidrasi $(17,1 \%)$. 


\section{Analisis Tabel Bivariat Status Dehidrasi Menurut Pola Konsumsi Cairan dari Minuman}

Analisis ini dilakukan untuk mengetahui hubungan antara pola konsumsi cairan dari minuman yang santriwati minum selama satu bulan terakhir terhadap status dehidrasinya saat ini. Untuk memudahkan peneliti dalam menggolongkan pola konsumsi cairan dari minuman, maka peneliti tidak lagi menggunakan katagori seperti pada analisis univariat pola konsumsi diatas. Jenis minuman dibagi dalam dua katagori baru, yaitu katagori 7 jenis minuman dan katagori lebih besar 7 jenis minuman berdasarkan pada merek terbanyak yang diminum.

Katagori ini didapat dari penjumlahan seluruh jenis minuman yang diminum oleh santriwati, kemudian jumlah ini dirata-ratakan. Hasil rata-rata yang didapat menunjukkan angka 7,35 , sehingga dilakukan pembulatan menjadi 7. Tujuh jenis minuman yang ada dalam katagori tersebut yaitu meliputi air minum tawar, susu, teh, jus, sari buah, softdrink, dan minuman elektrolit.

Berdasarkan hasil penelitian yang didapat menunjukkan bahwa yang mengalami dehidrasi banyak dijumpai pada santriwati yang mengonsumsi 7 jenis minuman $(31,6 \%)$. Sedangkan yang tidak mengalami dehidrasi banyak dijumpai pada santriwati yang mengonsumsi lebih 7 jenis minuman. Hal ini menunjukkan adanya kecenderungan hubungan antara pola konsumsi minuman dengan status dehidrasi.

Tabel 2

Distribusi Status Dehidrasi Menurut Pola Konsumsi Cairan Dari Minuman

\begin{tabular}{lcccccc}
\hline \multirow{2}{*}{ Pola Konsumsi Minuman } & \multicolumn{3}{c}{ Status Dehidrasi } & \multicolumn{2}{c}{ Total } \\
\cline { 2 - 6 } & \multicolumn{2}{c}{ Dehidrasi } & \multicolumn{2}{c}{ Tidak dehidrasi } & \multicolumn{2}{c}{} \\
\cline { 2 - 6 } & $\mathrm{n}$ & $\%$ & $\mathrm{n}$ & $\%$ & $\mathrm{n}$ & $\%$ \\
\hline 7 jenis & 6 & 31,6 & 13 & 68,4 & 19 & 100,0 \\
Lebih dari 7 jenis & 0 & 0,0 & 16 & 100,0 & 16 & 100,0 \\
\hline Total & 6 & 17,1 & 29 & 82,9 & 35 & 100,0 \\
\hline
\end{tabular}

\section{Analisis Tabel Bivariat Status Dehidrasi Menurut Jumlah Konsumsi Cairan dari Minuman}

Analisis ini dilakukan untuk mengetahui hubungan antara jumlah konsumsi cairan dari minuman yang diminum oleh santriwati selama satu hari terhadap status dehidrasinya. Seperti yang telah dijelaskan sebelumnya bahwa jumlah konsumsi cairan dikatakan cukup apabila $>1200 \mathrm{ml} / \mathrm{hari}$, sedangkan dikatakan kurang bila jumlah konsumsi cairan $<1200$ $\mathrm{ml} / \mathrm{hari}$.

Hasil menunjukkan bahwa mereka yang berstatus dehidrasi banyak dijumpai pada santriwati yang jumlah konsumsi cairannya kurang $(37,5 \%)$. Sedangkan yang tidak dehidrasi banyak dijumpai pada santriwati yang jumlah konsumsi cairannya cukup (100\%). Hal ini menunjukkan adanya kecenderungan hubungan antara jumlah konsumsi cairan terhadap status dehidrasi.

Tabel 3

Distribusi Status Dehidrasi Menurut Jumlah Konsumsi Cairan Dari Minuman

\begin{tabular}{|c|c|c|c|c|c|c|c|}
\hline \multirow{3}{*}{$\begin{array}{l}\text { Jumlah Konsumsi } \\
\text { dari Minuman }\end{array}$} & \multirow{3}{*}{ Cairan } & \multicolumn{4}{|c|}{ Status Dehidrasi } & \multirow{2}{*}{\multicolumn{2}{|c|}{ Total }} \\
\hline & & \multicolumn{2}{|c|}{ Dehidrasi } & \multicolumn{2}{|c|}{ Tidak dehidrasi } & & \\
\hline & & $\mathrm{n}$ & $\%$ & $n$ & $\%$ & $\mathrm{n}$ & $\%$ \\
\hline Kurang & & 6 & 37,5 & 10 & 62,5 & 16 & 100,0 \\
\hline Cukup & & 0 & 0,0 & 19 & 100,0 & 19 & 100,0 \\
\hline Total & & 6 & 17,1 & 29 & 82,9 & 35 & 100,0 \\
\hline
\end{tabular}




\section{BAHASAN}

Berdasarkan distribusi usia yang menjadi sampel dalam penelitian ini memang lebih banyak yang berusia 17 tahun. Hal ini dikarenakan santriwati yang dijadikan sampel lebih banyak diambil dari kelas 2 Aliyah. Sedangkan jenis minuman yang paling banyak dikonsumsi oleh santriwati dengan frekuensi sering yaitu air minum tawar dan jenis minuman yang paling banyak tidak dikonsumsi oleh santriwati yaitu jenis minuman sirup. Hal ini dikarenakan sirup sulit ditemui di dalam wilayah pesantren dan untuk mengonsumsi sirup menurut keterangan para santriwati tidak mudah karena harus ditambahkan dengan air tawar terlebih dahulu baru bisa diminum. Alasan ketidakpraktisan inilah yang menyebabkan banyak santriwati tidak pernah mengonsumsi sirup dalam satu bulan terakhir.

Jumlah cairan dari minuman yang dikonsumsi oleh santriwati lebih besar yang terkatagori cukup sehingga santriwati tidak mengalami dehidrasi. Berdasarkan hasil analisis terdapat adanya kecenderungan hubungan antara jumlah cairan yang dikonsumsi terhadap status dehidrasi. Hasil ini sejalan dengan penelitian yang pernah dilakukan oleh The Indonesian Hydration Regional Study pada tahun 2009 yang menyimpulkan bahwa kurangnya konsumsi air menyebabkan 49,5 persen remaja mengalami dehidrasi. ${ }^{1}$ Namun, hal ini berbeda dengan hasil penelitian yang dilakukan oleh Paramitha Rahma (2009) dengan sampel sebanyak 86 orang menunjukkan bahwa yang memiliki status dehidrasi banyak dijumpai pada siswi yang jumlah konsumsi cairannya cukup $(59,1 \%){ }^{6}$

\section{SIMPULAN}

Berdasarkan hasil analisis univariat usia dapat disimpulkan bahwa usia 18 tahun merupakan usia yang paling sedikit menjadi sampel $(11,4 \%)$. Kemudian berdasarkan hasil univariat distribusi pola konsumsi cairan dari minuman didapatkan kesimpulan bahwa air minum tawar merupakan air minum yang dikonsumsi oleh 100 persen sampel dengan frekuensi sering. Sedangkan berdasarkan hasil analisis univariat distribusi jumlah konsumsi cairan dari minuman didapatkan kesimpulan bahwa sampel dengan katagori cukup dalam mengonsumsi cairan yaitu sebanyak 54,3 persen. Hasil analisis univariat menunjukkan status dehidrasi sampel yang tidak mengalami dehidrasi sebanyak 82,9 persen.

Hasil analisis tabel bivariat antara pola konsumsi cairan dari minuman terhadap status dehidrasi didapatkan kesimpulan bahwa sampel yang mengonsumsi 7 jenis minuman mengalami dehidrasi, sehingga terdapat kecenderungan hubungan antara pola konsumsi cairan dari minuman terhadap status dehidrasi. Sedangkan berdasarkan hasil analisis tabel bivariat antara jumlah konsumsi cairan dari minuman terhadap status dehidrasi didapatkan kesimpulan bahwa sampel yang mengonsumsi cairan kurang mengalami dehidrasi sehingga ada kecenderungan hubungan antara jumlah konsumsi cairan dari minuman terhadap status dehidrasi.

\section{RUJUKAN}

1. Hardinsyah. Air Bagi Kesehatan. Jakarta: Centra Communications; 2011.

2. Sandjaja, Basuki Budiman, Moesijanti YE Sukatri, Rina Herarti, Haryati, Gustina Sofia dkk. Kamus Gizi Pelengkap Kesehatan Keluarga. Jakarta: Penerbit Kompas; 2009.

3. Batmanghelidj, F. Air Untuk Menjaga Kesehatan dan Menyembuhkan Penyakit. Jakarta:Gramedia; 2007

4. Tamsuri, Anas. 2004. Klien Gangguan Keseimbangan Cairan \& Elektrolit. Jakarta: EGC; 2004.

5. Bardosono, Saptawati. Air: Zat Gizi Esensial yang Terlupakan. Jakarta: Centra Communications; 2009.

6. Rahma, Paramita. Kebiasaan Minum, Kebutuhan Cairan, dan Kecenderungan Dehidrasi Siswi Sekolah Dasar. Skripsi. Bogor: Fakultas Ekologi Manusia Institut Pertanian Bogor; 2009. 